\title{
PERLINDUNGAN LINGKUNGAN DALAM PERSPEKTIF KEADILAN ANTAR GENERASI : SEBUAH PENELUSURAN TEORITIS SINGKAT
}

\author{
Andri G. Wibisana \\ Fakultas Hukum Universitas Indonesia \\ Jalan Prof. Mr Djokosoetono, Kampus Universitas Indonesia, Depok \\ mragw@yahoo.com
}

\begin{abstract}
This paper discusses environmental protection from the perspective of intergenerational equity. The paper attempts to answer the questions of how intergenerational equity will correspond to the various concepts of intertemporal planetary obligations, how it should affect the economic valuation of environmental resources, and how it could shape the intertemporal legal standing. The paper observes that intergenerationalequity can give rise to various obligations related to the conservation of options, quality, and access. The article is of the opinion that according to the principle of inter-generational equity the use of discounting in economic appraisal for future environmental damage should be modified to allow only the use of low discount rate. The article also discusses the importance of the Minors Oposa v. Factoran Jr. in providing a link between intergenerational equity and legal standing.
\end{abstract}

Keywords : sustainable development, intergenerational equity, legal standing

\begin{abstract}
Abstrak
Tulisan ini mendiskusikan perlindungan lingkungan di dalam kerangka keadilan antar generasi. Tujuan dari diskusi ini adalah memperkenalkan konsep keadilan lingkungan ini, serta untuk menjelaskan bagaimana keadilan antar generasi ini dikaitkan dengan kewajiban seluruh penghuni Bumi atas planetnya (planetary obligations), bagaimana relevansi keadilan dengan valuasi ekonomi, dan bagaimana hubungan keadilan antar generasi dengan hak gugat. Terkait planetary obligations, tulisan ini menggambarkan keadilan antar generasi sebagai kewajiban antara generasi untuk melakukan perlindungan generasi atas opsi, kualitas, dan akses terhadap sumber daya lingkungan. Terkait valuasi ekonomi, tulisan ini berpendapat bahwa penggunaan instrumen diskon di dalam penafsiran ekonomi perlu dimodifikasi menjadi diskon yang rendah, sehingga lebih sejalan keadilan antar generasi. Tulisan ini juga mendiskusikan pentingnya putusan Minors Oposa v. Factoran Jr. yang mengakui hak gugat antar generasi.
\end{abstract}

Kata Kunci : pembangunan berkelanjutan, keadilan antargenerasi, landasan hukum

\section{A. Pendahuluan}

"Determination of our obligations to others alive today, and to future generations, is an ethical question that must be answered prior to detailed decision making. It is not a question of efficiency, and is not a matter to be settled by cost-benefit analysis and consumer willingness to pay"-Frank Ackerman \& Lisa Heinzerling, Priceless: On Knowing the Price of Everything and the Value of Nothing.
Pada tahun 1987, World Commission on Environment and Development (WCED), atau sering disebut sebagai Komisi Brundtland (Brundtland Commission), mengeluarkan sebuah laporan yang berjudul Our Common Future. Melalui laporan ini, Komisi Brundtland mempopulerkan istilah pembangunan berkelanjutan (sustainable development) dan menempatkannya tepat di pusat pembuatan kebijakan internasional. Menurut Komisi ini, pembangunan berkelanjutan adalah pembangunan untuk 
memenuhi kebutuhan generasi sekarang tanpa mengganggu kemampuan generasi yang akan datang untuk memenuhi kebutuhan mereka ("development that meets the needs of the present without compromising the ability of future generations to meet their own needs")(Beder, 2006).

Menurut penjelasan Komisi Brundtland, definisi di atas mengandung dua unsur: unsur kebutuhan (needs) dan unsur keterbatasan (limitations). Terkait dengan unsur kebutuhan, Komisi beranggapan bahwa kebutuhan tersebut terutama adalah kebutuhan dari mereka yang miskin, yang harus merupakan prioritas dari upaya pemenuhan kebutuhan. Sedangkan terkait unsur keterbatasan, Komisi mengartikannya sebagai keterbatasan kemampuan lingkungan, yang diciptakan oleh kondisi teknologi dan organisasi sosial, untuk memenuhi kebutuhan generasi sekarang dan akan datang (World Commission on Environment and Development, 1987).

Sejalan dengan pandangan di atas, Sands membagi prinsip pembangunan berkelanjutan ke dalam beberapa prinsip/elemen hukum, yaitu: a). keadilan antar generasi (intergenerational equity), yang dapat dilihat dari kebutuhan untuk melindungi SDA bagi keuntungan generasi yang akan datang; b). pemanfaatan secara bekelanjutan (the principle of sustainable use), yang direfleksikan dalam eksploitasi SDA secara berkelanjutan (sustainable), hatihati (prudent), rasional (rational), bijaksana (wise), dan layak (appropriate); c). keadilan intra generasi, yang ditunjukkan melalui pemanfaatan SDA secara berkeadilan (equitable use of natural resources), di mana pemanfaatan SDA oleh satu negara tetap harus memperhatikan kebutuhan dari negara lain; dan d). prinsip integrasi (integration principle), yang meminta adanya jaminan bahwa pertimbangan lingkungan akan diintegrasikan ke dalam kebijakan ekonomi dan pembangunan, serta jaminan bahwa pemenuhan kebutuhan pembangunan harus memperhatikan tujuan perlindungan lingkungan (Sands, 1995). Dari paparan di atas terlihat bahwa keadilan lingkungan merupakan inti dari prinsip pembangunan berkelanjutan.

Tulisan ini bermaksud untuk membahas salah satu aspek dari keadilan lingkungan, yaitu keadilan antar generasi (intergenerational equity). Secara lebih spesifik, tulisan ini akan menjawab pertanyaan bagaimana keadilan antar generasi dilihat sebagai kewajiban seluruh penghuni Bumi atas planetnya (planetary obligations). Terkait pertanyaan ini, tulisan ini akan memperlihatkan keadilan antar generasi sebagai kewajiban intertemporal terkait perlindungan lingkungan. Selanjutnya, tulisan ini akan menjawab pula bagaimana relevansi keadilan dengan valuasi ekonomi. Tulisan ini akan memasukkan keadilan antar generasi ke dalam diskusi tentang diskon (discounting) terhadap manfaat perlindungan lingkungan di dalam konteks valuasi ekonomi. Terakhir, tulisan ini juga akan menjawab pertanyaan bagaimana hubungan keadilan antar generasi dengan hak gugat. Dalam hal ini, tulisan ini akan memperlihatkan pengakuan hak gugat antar generasi sebagai konsekuensi dari pengakuan terhadap hak atas lingkungan dan keadilan antar generasi.

Untuk menjawab pertanyaanpertanyaan di atas, tulisan ini akan disusun ke dalam beberapa bagian. Setelah Bagian Pendahuluan ini (Bagian A), Bagian B.1 akan mendiskusikan keterkaitan keadilan antar generasi dengan kewajiban antar generasi yang diemban oleh generasi sekarang dalam rangka melakukan perlindungan lingkungan. Secara spesifik, diskusi dalam Subbagian ini akan menggunakan perspektif planetary obligations sebagaimana dijelaskan oleh Edith Brown Weiss. Terkait hal ini, tulisan ini akan melihat keadilan antar generasi sebagai perlindungan atas pilihan (opsi), kualitas dan akses. Selanjutnya, Bagian B.2 akan menjelaskan Di sisi lain dalam bagian ini pun akan didiskusikan penggunaan "diskon" dalam analisa ekonomi ditinjau dari perspektif keadilan antar generasi. Bagian B.3 akan mendiskusikan keterkaitan antara keadilan antar generasi dengan hak gugat. Secara spesifik, Subbagian ini akan 
memperlihatkan bagaimana putusan Mahkamah Agung Filipina dalam Minors Oposa v. Factoran Jr akan memberikan arah baru yang lebih kongkret bagi penerapan keadilan antar generasi dan hak atas atas lingkungan yang baik. Bagian $\mathrm{C}$ memaparkan beberapa kesimpulan.

\section{B. Pembahasan}

\section{Keadilan Antar Generasi dan Kewajiban Antar Generasi}

Dalam pandangan Weiss, konsep keadilan antara generasi telah melahirkan kewajiban lingkungan terhadap Bumi (planetary obligations) berupa tiga jenis perlindungan, yaitu: perlindungan atas opsi (conservation of options), perlindungan atas kualitas (conservation of quality), dan perlindungan atas akses (conservation of access) (Weiss, 1996). Ketiga aspek perlindungan ini bertujuan agar setiap generasi memiliki tingkat pemanfaatan yang setidaknya sama dengan tingkat pemanfaatan dari generasi sebelumnya, sambil mendorong terjadinya perbaikan keadaan bagi tiap generasi. Ketiganya berfungsi pula untuk menetapkan batasan bagi tiap negara ketika mengeksploitasi sumber daya miliknya. Lebih penting lagi, ketiga aspek perlindungan ini memiliki peran untuk mengubah asumsi pembangunan, dari asumsi yang mendorong terjadinya konsumsi dan eksploitasi selama belum ada alasan untuk menghentikannya, menjadi asumsi yang menginginkan adanya pemanfaatan sumber daya alam secara berkelanjutan dan perlindungan lingkungan selama belum ada alasan kuat untuk tidak melakukan pemanfaatan berkelanjutan dan perlindungan tersebut(Sohn \& Weiss, 1987).

Perlindungan atas opsi (conservation of options) diartikan sebagai perlindungan terhadap keanekaragaman sumber daya yang tersedia. Menurut Weiss, perlindungan opsi ini tidaklah berarti bahwa kondisi status quo harus dilindungi, karena perlindungan seperti ini hanya akan melanggenggkan kondisi hidup dari mereka yang miskin. Sebaliknya, Weiss berpendapat bahwa perlindungan opsi dapat berarti perbaikan kehidupan, yang dicapai melalui pengembangan teknologi dan penciptaan berbagai alternatif sumber daya alam, sambil melakukan upaya pemanfaatan secara lebih efisien dan perlindungan terhadap sumber daya alam yang saat ini tersedia. Tujuannya adalah tercapainya keseimbangan keanekaragaman sumber daya alam (Sohn \& Weiss, 1987). Dengan demikian, perlindungan opsi menginginkan agar keberagaman pilihan atas sumber daya alam yang dimiliki oleh generasi yang akan datang, setidaknya, tidak lebih buruk dari keberagaman pilihan yang dimiliki oleh generasi sekarang.

Perlindungan atas kualitas (Conservation of Quality) menyatakan bahwa generasi sekarang memikul beban untuk memastikan bahwa kualitas lingkungan dan sumber daya alam yang dimiliki oleh generasi yang akan datang tidak akan lebih buruk dari kualitas yang dimiliki oleh generasi sekarang. Hal ini tidak berarti kondisi lingkungan saat ini tidak boleh berubah, sebab jika demikian halnya maka perlindungan atas kualitas akan bertentangan dengan perlindungan atas akses yang memang memungkinkan adanya pemanfaatan lingkungan. Lebih jauh lagi, dalam pandangan Weiss, perlindungan kualitas memerlukan adanya pengembangan ukuran mengenai kualitas sumber daya lingkungan, serta peningkatan kapasitas pengetahuan dan kemampuan manusia untuk memprediksi titik kritis (breaking points) dari sistem alam dan sosial yang ada (Sohn \& Weiss, 1987).

Perlindungan atas akses (conservation of access) mencerminkan adanya alokasi hak dan akses terhadap sumber daya alam yang seimbang antar generasi yang berbeda dan antar sesama anggota dari generasi sekarang. Dengan demikian, perlindungan akses memberikan hak yang adil (equitable rights) dan non-diskriminatif bagi setiap warga dari generasi sekarang untuk menggunakan sumber daya lingkungan. Namun demikian, dalam penggunaan sumber daya ini, setiap anggota generasi sekarang memiliki kewajiban (equitable duties) untuk menjamin bahwa tindakannya tidak akan mengurangi akses generasi yang akan datang atas sumber daya tersebut (Sohn \& Weiss, 1987). Dalam 
bahasa Beder, perlindungan akses mengindikasikan bahwa "current generations should ensure that future generations can also enjoy this access. Equity and fairness would seem to require that future generations not only be able to subsist but that they have the same level of opportunities to thrive and be happy as current generations" (Beder, 2006).

Adanya kewajiban antar generasi yang diemban oleh generasi sekarang dapat dibenarkan karena beberapa alasan. Pertama, dalam pandangan utilitarian yang melihat bahwa ukuran yang digunakan untuk menentukan apakah sebuah tindakan itu benar atau tidak adalah hasil akhir dari tindakan tersebut, yaitu apakah tindakan tersebut menghasilkan kebahagiaan yang terbesar atau tidak (Alder \& Wilkinson, 1999). Dengan demikian, apabila kebahagiaan, sebagai ukuran baik tidaknya sebuah tindakan, ditarik sehingga melampaui batas generasi, maka sepintas kita akan melihat aspek keberlanjutan dari etika utilitarianisme(Alder \& Wilkinson, 1999).

Dalam konteks ini, pemaksimalan kesejahteraan sebagai tujuan dari utilitarianisme haruslah bersifat nondiskrimitatif terhadap waktu, dalam arti bahwa setiap generasi harus dipandang memiliki kepentingan dan bobot yang sama, sehingga ukuran kesejahteraan haruslah kesejahteraan yang bersifat lintas generasi (Alder \& Wilkinson, 1999). Kebahagiaan atau kesejahteraan generasi sekarang tidak boleh dianggap lebih tinggi atau lebih bernilai $\mathrm{d}$ i b a $\mathrm{n} \mathrm{d}$ i $\mathrm{n} \mathrm{g} \mathrm{k} \mathrm{a} \mathrm{n} \quad \mathrm{d}$ e $\mathrm{n} \mathrm{g}$ a $n$ kebahagiaan/kesejahteraan dari generasi yang akan datang (Alder \& Wilkinson, 1999). Atas dasar inilah maka prinsip utilitarian ideal ini menjadi dekat dengan aliran "enlightened anthropocentrism", yang melihat bahwa perlindungan terhadap kepentingan manusia pada akhirnya memerlukan juga perlindungan dan pemeliharaan sistem lingkungan yang berfungsi menyokong kehidupan manusia (environmental life supporting system) (Alder \& Wilkinson, 1999).

Kedua, pandangan deontologis, yang menolak gagasan bahwa nilai suatu tindakan ditentukan oleh hasil akhirnya, mengajukan gagasan yang didasarkan pada hak (rights) dan kewajiban (duties), di mana suatu tindakan yang bernilai baik pada dirinya (intrinsic value) dilakukan karena tindakan itu sendiri sudah merupakan tujuan (Alder \& Wilkinson, 1999). Berdasarkan pandangan deontologis ini, tindakan perlindungan lingkungan dapat dianggap merupakan imperatif kategoris, yang diinginkan oleh semua orang, baik yang hidup pada generasi sekarang maupun generasi yang akan datang. Sebaliknya, karena perbuatan pencemaran saat ini kemungkinan akan menimbulkan akibat pada masa yang akan datang, maka kita pun dapat berasumsi bahwa pencemaran lingkungan tidak akan diinginkan secara universal (Alder \& Wilkinson, 1999). Dengan demikian, maka pembangunan berkelanjutan dapat pula dianggap sebagai upaya yang merupakan imperatif kategoris, yang diinginkan oleh segenap manusia pada setiap generasi.

Ketiga, beban generasi sekarang terkait perlindungan lingkungan dapat dikaitkan bula dengan pandangan Rawls tentang keadilan. Menurut Rawls, penerapan prinsip keadilan pada hubungan antar generasi dapat dilihat dari apa yang disebutnya sebagai "just saving principle" (Rawls, 1999). Dalam hal ini, Rawls menyatakan bahwa

"persons in different generations have duties and obligations to one another just as contemporaries do. The present generation cannot do as it pleases but is bound by the principles that would be chosen in the original position to define justice between persons at different moments of time. In addition, men have a natural duty to uphold and to further just institutions and for this the improvement of civilization up to a certain level is required."(Rawls, 1999).

Berdasarkan kutipan di atas, maka dalam perspektif Rawlsian perlindungan lingkungan dapat dibenarkan karena dua alasan. Pada satu sisi, perlindungan lingkungan oleh generasi sekarang 
merupakan upaya yang memang akan diambil oleh para pihak yang berada dalam posisi asali, yaitu dalam keadaan keserbataktahuan (the veil of ignorance). Para pihak yang tidak tahu apakah mereka akan hidup sekarang atau pada masa yang akan datang, ketika dihadapkan pada pilihan apakah akan memanfaatkan sumber daya secara berkelanjutan atau menghabiskan sumber daya saat ini dan menyisakan kerusakaan alam di masa datang, diasumsikan akan memilih pilihan yang pertama. Hal ini terjadi karena dengan memilih pilihan yang pertama, maka para pihak terhindar dari kemungkinan terburuk, yaitu ketika mereka ternyata hidup di masa yang akan datang (dan dalam keadaan lingkungan yang telah rusak dan sumber daya yang telah habis). Pada sisi lain, pandangan Rawls bahwa setiap generasi memiliki kewajiban alamiah untuk menyisihkan (sumber daya) bagi generasi yang akan datang, menunjukkan bahwa keberlanjutan pemanfaatan sumber daya merupakan sebuah tindakan yang bersifat universal. Dalam konteks ini, maka penjelasan Rawlsian atas pembangunan berkelanjutan menjadi sejalan dengan pandangan kaum deontologis.

\section{Keadilan antar Generasi vs Diskonting dalam Perhitungan Ekonomi}

Meskipun secara konsep keadilan antar generasi dapat secara mudah dipahami, tetapi dalam prakteknya hal ini sangat sulit dilaksanakan. Salah satu praktek yang menunjukkan adanya penyimpangan terhadap keadilan antar generasi dapat kita lihat dalam penggunaan tingkat diskon (discount rate) pada perhitungan ekonomi valuasi ekonomi dan analisa biaya-manfaat (Cost-Benefit Analysis - CBA) bagi kegiatan perlindungan lingkungan. Menurut CBA, sebuah upaya perlindungan dapat dibenarkan hanya jika nilai manfaat masa kini (present benefit) dari upaya perlindungan lebih besar atau sama dengan biaya yang harus dikeluarkan untuk melakukan upaya perlindungan saat ini (Turner, Pearce, \& Bateman, 1993).

Ambil contoh misalnya perhidungan ekonomi terkait perubahan iklim. Dalam konteks ini, penggunaan tingkat diskon berfungsi untuk mengurangi besaran dampak perubahan iklim, sehingga "sesuai" dengan perspektif masa kini. Semakin tinggi tingkat diskon, semakin kecil dampak perubahan iklim di masa depan jika dilihat dari kaca mata masa kini. Akibatnya, biaya pencegahan perubahan iklim yang diizinkan pun akan semakin rendah. Kondisi ini kemudian akan bermuara pada semakin rendahnya tingkat penurunan emisi yang diperlukan.

Kajian dari Tol memperlihatkan bagaimana perbedaan tingkat diskon merupakan faktor yang sangat mempengaruhi hasil estimasi ekonomi dari dampak perubahan iklim. Dalam temuan Tol, dengan tingkat diskon sebesar $10 \%$, MSC yang dihasilkan berkisar 6 US\$/tC. Ketika tingkat diskon diturunkan menjadi 5\%, MSC naik menjadi $26 \mathrm{US} \$ / \mathrm{tC}$, dan ketika tingkat diskon diturunkan lagi menjadi 0 (nol), MSC naik sampai 317 US\$/tC (Tol, 1999). MSC merupakan singkatan dari Marginal Social Cost. Istilah untuk menunjukkan seberapa dampak yang akan dihasilkan dari penambahan emisi sebesar 1 ton karbon, atau seberapa dampak yang akan dicegah dari penghilangan 1 ton karbon dari atmosfir. Dari penelitian Tol ini, dapat dilihat bahwa penentuan tingkat diskon ternyata sangat mempengaruhi hasil perhitungan dan rekomendasi yang diberikan. Estimasi dampak yang tinggi, yang menunjukkan pentingnya penurunan emisi, dan karenanya menghasilkan rekomendasi penurunan emisi yang tinggi dihasilkan jika estimasi menggungakan tingkat diskon yang rendah, atau bahkan tidak menggunakan sama sekali.

Pertanyaannya tentu saja adalah mengapa perhitungan ekonomi atas kebijakan mengenai upaya perlindungan lingkungan harus menggunakan tingkat diskon tertentu? Terdapat beberapa alasan yang sering dikemukakan oleh para ekonom. Tulisan ini bermaksud membantah setiap alasan yang diberikan tersebut, dan menunjukkan bahwa berdasarkan keadilan antar generasi, penggunaan tingkat diskon seharusnya tidak dilakukan, atau jika harus digunakan pun maka tingkat diskon tersebut haruslah rendah. 
Alasan yang sering digunakan untuk membenarkan penggunaan diskon terhadap dampak lingkungan di masa depan adalah bahwa penggunaan diskon ini merefleksikan perilaku individu manusia. Dalam hal ini, seringkali dikatakan bahwa diskon (terhadap dampak di masa depan) digunakan sebab manusia diasumsikan bersikap tidak sabar, dalam arti bahwa manusia lebih menyukai konsumsi saat ini dibandingkan dengan konsumsi pada masa depan. Dalam ekonomi, ketidaksabaran ini disebut sebagai "pure time preference", yang menunjukan preferensi manusia terhadap masa sekarang dibandingkan dengan masa yang akan datang, sehingga mengindikasikan pula preferensi manusia atas kepentingan masa sekarang dibandingkan dengan kepentingan masa yang akan datang. Pendapat ini perlu dipertanyakan sebab meskipun kita, misalnya, menerima asumsi ketidaksabaran individu, namun asumsi ini tidak bisa diterapkan bagi kebijakan publik. Individu dapat saja bersikap tidak sabar karena mereka percaya bahwa mereka tidak akan hidup selamanya. Tetapi pembuat kebijakan tidak bisa menggunakan asumsi yang berasal dari sikap individu ini karena pembuat kebijakan harus berpikir bahwa dampak positif dari keputusan yang diambilnya tidak hanya dirasakan oleh dirinya dan generasi sekarang, tetapi juga oleh mereka yang hidup di masa depan. Atas dasar ini, Khanna dan Chapman berpendapat bahwa penggunaan diskon atas dasar "pure time preference" untuk kebijakan lingkungan, seperti perubahan iklim, tidaklah memiliki dasar etik. Kebijakan publik haruslah didasarkan pada asumsi "immortal society", dan bukan pada "mortal individuals"(Khanna \& Chapman, 1996).

Pembenaran lain yang sering diketengahkan terkait penggunaan diskon adalah asumsi mengenai "diminishing marginal utility", penurunan perubahan utilitas relatif terhadap peningkatan kekayaan. Dalam hal ini, diasumsikan bahwa pembangunan yang dilakukan sekarang akan membawa kemakmuran tidak hanya bagi generasi sekarang, tetapi juga bagi generasi yang akan datang, sehingga generasi yang akan datang diasumsikan akan lebih kaya dari pada generasi sekarang. Dengan asumsi ini maka tingkat diskon digunakan untuk merefleksikan "diminishing marginal utility", yang muncul sebagai akibat dari peningkatan kekayaan dari waktu ke waktu. Pendapat ini pun cukup problematik, karena apabila kita memutuskan untuk tidak melakukan upaya perlindungan lingkungan dan hanya peduli dengan tingkat pertumbuhan - misalnya saja kita memutuskan untuk tidak melakukan pengurangan emisi gas rumah kaca, sebab dengan demikian kita bisa melakukan penghematan uang - maka kita sebenarnya sedang menciptakan kemungkinan munculnya bencana di masa depan. Dengan peningkatan kemungkinan bencana di masa depan ini, maka asumsi bahwa generasi masa depan akan lebih kaya dari generasi sekarang menjadi perlu untuk dipertanyakan kembali. Alih-alih membuat generasi yang akan datang menjadi lebih kaya, jika tindakan kita menimbulkan kemungkinan munculnya bencana di masa depan, maka kita justru sedang memiskinkan, atau bahkan memusnahkan, generasi yang akan datang. Dalam konteks inilah, Gollier berpendapat bahwa ketidakpastian mengenai pertumbuhan ekonomi di masa depan seharusnya mendorong pembuat kebijakan untuk menerapkan tingkat diskon yang rendah. Dalam pandangan Gollier, tingkat diskon yang rendah ini merupakan tindakan prudent untuk mengantisipasi kemungkinan bencana di masa depan, sebagai akibat dari pembangunan yang dilakukan sekarang (C. Gollier, 2002).

Terkait dengan penggunaan diskon karena alasan pertumbuhan, terdapat pula pendapat yang menganggap bahwa kemakmuran di masa depan merupakan hasil dari pembangunan masa sekarang, yang hanya bisa terjadi jika generasi sekarang menggunakan tingkat diskon yang tinggi. Pendapat ini menganggap bahwa karena pembangunan sekarang tidak hanya berpotensi menimbulkan dampak negatif tetapi juga dampak positif berupa kemakmuran di masa depan, maka kemakmuran ini merupakan "kompensasi" 
atas munculnya dampak negatif di masa depan. Atas asumsi dan pendapat ini, Spash mengatakan bahwa kita perlu membedakan antara transfer kebutuhan dasar dari generasi sekarang ke generasi yang akan datang-dalam bentuk kemakmuran bagi generasi yang akan datang-dengan kompensasi. Keduanya, menurut Spash didasarkan pada landasan etik yang berbeda. Jika transfer kemakmuran didasarkan pada keadilan distributif, maka kompensasi didasarkan pada keadilan korektif. Keadilan distributif tidak bisa menghapuskan keadilan korektif, dalam arti bahwa kemampuan kita memberikan kemakmuran bagi seseorang, tidak lantas memberikan hak kepada kita untuk secara sadar merugikan dan membahayakan orang tersebut. Apabila kita melakukan ini, maka keadilan korektif menuntut kita untuk memperbaiki keadaan dan memberikan kompensasi kepada orang tersebut (C.L. Spash, 1994). Lebih jauh lagi, Spash menyatakan bahwa jika setiap orang memiliki kebebasan dari ancaman bahaya yang ditimbulkan oleh orang lain, maka apabila bahaya tersebut tidak bisa dicegah, kompensasi haruslah actual (C.L. Spash, 1994). Apabila dapat diasumsikan bahwa kompensasi aktual antar generasi bukanlah sesuatu yang mungkin, maka penggunaan tingkat diskon seharusnya ditiadakan.

Terakhir, penggunaan diskon juga seringkali dibenarkan atas dasar pertimbangan lingkungan. Dalam pandangan ini, apabila penggunaan tingkat diskon juga digunakan untuk penentuan tingkat investasi, maka tingkat diskon yang tinggi memiliki potensi untuk mengurangi tingkat pembangunan saat ini. Dengan adanya pengurangan tingkat pembangunan - sebagai akibat tingkat diskon yang tinggi-maka penipisan sumber daya alam dapat dikurangi. Sebaliknya, penggunaan tingkat diskon yang rendah, justru akan menghasilkan tingkat penipisan sumber daya alam yang lebih tinggi. Tingkat diskon yang tinggi, karenanya, bagus bagi lingkungan (Pearce \& Turner, 1991). Broome menyatakan bahwa pandangan di atas secara tepat telah mengingatkan kita akan bahaya lingkungan hidup dari pembangunan yang hanya memfokuskan perhatian pada pertumbuhan. Akan tetapi, menurut Broome, pandangan di atas keliru ketika menyalahkan tingkat diskon yang rendah sebagai penyebab munculnya ancaman bahaya lingkungan. Bagi Broome, persoalan lingkungan muncul sebagai akibat dari eksternalitas, dan bukan akibat dari tingkat diskon yang rendah. Karenanya, bagi Broome, solusi dari persoalan lingkungan ini adalah internalisasi eksternalitas, dan bukannya penggunaan tingkat diskon yang tinggi(Broome, 1992).

Secara singkat, artikel ini hendak menyatakan bahwa dalam perspektif keadilan antar generasi, maka terdapat berbagai alasan untuk menghilangkan faktor "pure time preference" dalam tingkat diskon. Pada akhirnya, penghilangan faktor ketidaksabaran, myopia, ini akan bermuara pada penggunaan tingkat diskon yang rendah, atau bahkan nol. Dan ini sejalan dengan keadilan antar generasi, terutama untuk menjamin bahwa tindakan generasi sekarang tidak akan menciptakan kemungkinan munculnya bencana besar bagi generasi yang akan datang.

\section{Keadilan antar Generasi dan Hak Gugat antar Generasi}

Secara hukum, pengakuan terhadap keadilan antar generasi dapat dilihat dari putusan Mahkamah Agung Filipina dalam kasus Minors Oposa v. Factoran. Kasus ini adalah kasus gugatan anak-anak di bawah umur, yaitu Juan Antonio Oposa, Anna Rosario Oposa, dan Jose Alfonso Oposa, yang diwakili oleh orang tua mereka Antonio Oposa dan Rizalina Oposa, serta beberapa anak di bawah umur lainnya yang masingmasing diwakili oleh orang tua mereka. Para penggugat ini menggunakan class action dari para pembayar pajak, dan menyatakan bahwa mereka adalah warga negara Filipina yang mewakili generasi mereka dan juga generasi yang akan datang (Supreme Court of the Philippines, 1994). Para penggugat ini menggugat Department of Environment and Natural Resources (DENR), dalam hal ini Factoran, Jr. sebagai sekretaris departemen, terkait dengan pengelolaan kehutanan di 
Filipina. Penggugat menyatakan bahwa kebijakan kehutanan Filipina, yang telah mengizinkan eksploitasi hutan secara besarbesarang, merupakan pelanggaran hak konstitusional para penggugat dan generasi yang akan datang atas lingkungan yang baik dan sehat (Supreme Court of the Philippines, 1994). Atas dasar itu, penggugat meminta agar pengadilan memerintahkan tergugat untuk menghentikan semua izin penebangan (timber licensing agreements-TLA) yang telah ada, pembaruan izin lama, atau pemberian izin baru (Supreme Court of the Philippines, 1994).

Atas gugatan tersebut, tergugat pada satu sisi menyatakan bahwa TLA merupakan kebijakan yang didasarkan pada diskresi sehingga tidak bisa digugat, dan bahwa TLA adalah kontrak yang harus dilindungi sehingga pencabutannya haruslah sesuai dengan prosedur. Lebih penting lagi, pada sisi lain tergugat menyatakan bahwa para penggugat tidak memiliki hak gugat (cause of action, maupun locus standi) karena hak atas lingkungan yang baik bukanlah hak yang cukup spesifik (specific legal right) untuk dijadikan dasar gugatan (Supreme Court of the Philippines, 1994).

Setelah memperhatikan berbagai putusan pengadilan terkait dengan izin penebangan, Mahkamah Agung memutuskan bahwa TLA bukanlah kontrak. Seandainya pun TLA dianggap kontrak, maka keberlakukannya tidaklah bersifat absolut. Artinya, sebagai kontrak pun TLA masih dapat dihentikan, jika TLA melanggar hak orang lain atas lingkungan yang baik (Supreme Court of the Philippines, 1994).

Lebih penting lagi, Mahkamah Agung Filipina mengakui bahwa hak atas lingkungan hidup merupakan hak konstitusional yang tidak hanya dimiliki oleh generasi sekarang, tetapi juga oleh generasi yang akan datang. Atas dasar inilah maka pengadilan menyatakan bahwa penggugat memiliki hak gugat untuk menggugat bagi kepentingannya sendiri serta sekaligus atas nama kepentingan generasi yang akan datang. Dalam hal ini, Mahkamah Agung Filipina menyatakan:

"This case, however, has a special and novel element. Petitioners minors assert that they represent their generation as well as generations yet unborn. We find no difficulty in ruling that they can, for themselves, for others of their generation and for the succeeding generations, file a class suit. Their personality to sue in behalf of the succeeding generations can only be based on the concept of intergenerational responsibility insofar as the right to a balanced and healthful ecology is concerned. Such a right, as hereinafter expounded, considers the "rhythm and harmony of nature." Nature means the created world in its entirety. Such rhythm and harmony indispensably include, inter alia, the judicious disposition, utilization, management, renewal and conservation of the country's forest, mineral, land, waters, fisheries, wildlife, off-shore areas and other natural resources to the end that their exploration, development and utilization be equitably accessible to the present as well as future generations. Needless to say, every generation has a responsibility to the next to preserve that rhythm and harmony for the full enjoyment of a balanced and healthful ecology. Put a little differently, the minors' assertion of their right to a sound environment constitutes, at the same time, the performance of their obligation to ensure the protection of that right for the generations to come-[catatan kaki diabaikan]."'(Supreme Court of the Philippines, 1994)

Di samping itu, Mahkamah Agung juga menyatakan bahwa hak atas lingkungan hidup yang baik dan sehat tidak kalah pentingnya dibandingkan dengan hak sipil dan politik. Hak-hak asasi ini, menurut Mahkamah Agung, bahkan tidak akan berkurang nilainya jika tidak dicantumkan di dalam Konstitusi, sebab hak-hak ini 
merupakan hak asasi yang muncul seiring keberadaan manusia. Pencantuman hak atas lingkungan yang baik di dalam Konstitusi dilakukan untuk menggarisbawahi pentingnya hak tersebut dan untuk mengaskan adanya kewajiban negara untuk melindungi dan memajukan hak tersebut. Menurut pandangan Mahkamah Agung, apabila hak tersebut tidak tercantum di dalam Konstitusi, maka tidak akan lama lagi generasi sekarang akan mengalami musnahnya sumber daya lingkungan, serta tidak akan mampu mewariskan apa-apa kepada generasi yang akan datang, kecuali lingkungan hidup yang sudah tidak mampu lagi untuk menyangga kehidupan. Hak atas lingkungan hidup yang baik, karenanya, melahirkan kewajiban untuk tidak menyebabkan gangguan pada lingkungan hidup (Supreme Court of the Philippines, 1994).

Putusan Mahkamah Agung Filipina ini segera mendapat sambutan dan kritik, baik dalam skala nasional maupun internasional. Kritik menyatakan bahwa pada tataran praktis, putusan ini tidaklah berarti apa-apa, karena putusan ini tidaklah mencabut atau menghentikan TLA yang telah ada; sedang pada tataran teoritis, pengakuan hak gugat bagi generasi sekarang dan generasi yang akan datang, sebagai wujud dari pengakuan terhadap keadilan antar generasi, merupakan hal yang dibesar-besarkan dan bersifat obiter dictum, sebab meskipun mengakui keadilan antar generasi, pengadilan tidak memberikan pendapat yang jelas mengenai hak gugat (dari generasi yang akan datang) (Gatmaytan, 2003). Pendapat yang skeptis juga menyatakan bahwa, meskipun penting, keberlakuan putusan Minors Oposa v. Factoran hanya terbatas pada pengakuan keadilan antar generasi secara nasional, dan tidak bisa dijadikan bukti bahwa keadilan ini telah mendapatkan pengakuan dan dipraktekkan secara luas secara di seluruh Negara(Barresi, 1998).

Namun demikian, perlu ditegaskan di sini bahwa putusan Minors Oposa v. Factoran tetaplah memiliki arti yang sangat penting bagi pengakuan dan implementasi keadilan antar generasi. Ada beberapa alasan yang dapat dikemukakan untuk mendukung pernyataan ini. Pertama, secara praktis, meskipun pengadilan tidak memutuskan mencabut atau menghentikan TLA, faktanya pada tahun 2006 hanya terdapat 3 (tiga) TLA (satu di antaranya tidak aktif, dan satu lagi dalam proses review). Di sisi lain, putusan Minors Oposa v. Factoran pun telah menginspirasi lahirnya beberapa putusan pengadilan di Filipina yang melahirkan putusan yang mendukung upaya perlindungan lingkungan hidup (Houck, 2007). Kedua, putusan Minors Oposa v. Factoran memberikan penegasan bahwa hak atas lingkungan yang baik merupakan hak yang dapat ditegakkan, sehingga dapat menjadi dasar gugatan bagi pihak yang merasa hak tersebut telah dilanggar (actionable right) (Manguiat \& III, 2003). Dalam hal ini, actionable right tersebut bukan hanya dimiliki oleh generasi sekarang, tetapi juga oleh generasi yang akan datang. Ketiga, pengakuan putusan Minors Oposa v. Factoran atas keadilan antar generasi dan kaitannya hak gugat, tidaklah bersifat obiter dictum. Sebaliknya, pada saat putusan Minors Oposa v. Factoran secara langsung mengaitkan antara hak atas lingkungan yang baik dari generasi sekarang dengan hak atas lingkungan yang baik dari generasi yang akan datang, maka putusan tersebut dapat dianggap telah menjadi dasar preseden mengenai bagaimana hak atas lingkungan yang baik dapat ditafsirkan dan ditegakkan, serta sejauhmana hak tersebut dapat dikaitkan dengan hak konstitusional dari generasi yang akan datang (Manguiat \& III, 2003). Dalam hal ini, putusan Minors Oposa v. Factoran secara tegas menyatakan bahwa karena hak atas lingkungan yang baik dimiliki baik oleh generasi sekarang maupun generasi yang akan datang, maka generasi sekarang dapat melakukan gugatan tidak hanya untuk melindungi haknya tersebut, tetapi juga hak dari generasi yang akan datang (Supreme Court of the Philippines, 1994). Keempat, seperti dinyatakan oleh Maggio, putusan Minors Oposa v. Factoran memiliki arti yang sangat penting karena untuk pertama kalinya 
sebuah lembaga pengadilan tertinggi secara tegas mengakui adanya keadilan antar generasi, dan kemudian mengaitkan pengakuan tersebut dengan hak gugat dari generasi yang akan datang (G.F. Maggio, 1997).

Mengingat bahwa Indonesia pada satu sisi telah mengakui adanya hak atas lingkungan yang baik dan sehat sebagai hak konstitusional, serta pada sisi lain telah pula mengakui keadilan intra dan antar generasi, serta berbagai hak gugat, maka sangatlah tepat jika pada suatu saat pengadilan Indonesia pun mampu mengikuti pengadilan Filipina, untuk memutuskan bahwa: pertama, hak atas lingkungan yang baik merupakan actionable right yang dimiliki baik oleh generasi sekarang maupun generasi yang akan datang; dan karenanya, kedua, hak gugat tidak hanya dimiliki oleh generasi sekarang, tetapi juga dimiliki oleh generasi yang akan datang.

\section{Simpulan}

Secara etis, keadilan antar generasi dapat melahirkan berbagai kewajiban (planetary obligations) dari setiap generasi untuk menjamin perlindungan terhadap opsi (conservation of options), perlindungan terhadap kualitas lingkungan (conservation of quality), dan perlindungan terhadap akses generasi sekarang dan generasi yang akan datang terhadap sumber daya lingkungan (conservation of access). Secara ekonomi, keadilan antar generasi harus mempengaruhi valuasi ekonomi dan CBA terhadap manfaat perlindungan lingkungan. Dalam hal ini, penggunaan instrumen diskon di dalam penafsiran ekonomi perlu dimodifikasi menjadi diskon yang rendah, sehingga lebih sejalan keadilan antar generasi. Secara khusus, tulisan ini memperlihatkan perlunya penghapusan diskon manfaat perlindungan lingkungan yang didasarkan karena alasan pure time preference. Secara hukum, putusan Mahkamah Agung Filipina dalam kasus Minors Oposa v. Factoran telah mampu secara brillian mengaitkan antara keadilan antar generasi dengan hak gugat.

\section{DAFTAR PUSTAKA}

Alder, J., \& Wilkinson, D. (1999). Environmental Law and Ethics. London: Macmillan Press.

Barresi, P. A. (1998). Advocacy, Frame, and the Intergenerational Imperative: A Reply to Professor Weiss on "Beyond Fairness to Future Generations." Tulane Environmental Law Journal, 11(2), 434.

Beder, S. (2006). Environmental Principles and Policies: An Interdisciplinary Introduction. New York: Earthscan.

Broome, J. (1992). Counting the Cost of Global Warming. Cambridge: The White Horse Press.

C. Gollier. (2002). Discounting an Uncertain Future. Journal of Public Economics, 85,153154 .

C.L. Spash. (1994). Double CO2 and Beyond: Benefits, Costs and Compensation. Ecological Economics, 10,32 .

G.F. Maggio. (1997). Inter/intra-generational Equity: Current Applications under International Law for Promoting the Sustainable Development of Natural Resources. Buffalo Environmental Law Journal, 4(2), 192.

Gatmaytan, D. B. (2003). The Illusion of Intergenerational Equity: Oposa v. Factoran as Pyrrhic Victory. Georgetown International Environmental Law Review, 15(3), 466468.

Houck, O. A. (2007). Light from the Trees: The Stories of Minors Oposa and the Russian Forest Cases. Georgetown International Environmental Law Review, 19(3), 339341.

Khanna, N., \& Chapman, D. (1996). Time Preference, Abatement Costs, and International Climate Policy: An Appraisal of IPCC 1995. Contemporary Economic Policy, XIV(2), 58.

Manguiat, M. S. Z., \& III, V. P. B. Y. (2003). Maximizing the Value of Oposa $v$. Factoran. Georgetown International Environmental Law Review, 15(3), 496.

Pearce, D. W., \& Turner, R. K. (1991). Economics of natural Resources and the Environment, 2nd ed. Baltmore: Johns Hopkins University Press. 
Rawls, J. (1999). A Theory of Justice, revised ed. Oxford: Oxford University Press.

Sands, P. (1995). Principles of International Environmental Law: Vol. 1, Frameworks, Standards, and Implementation. Manchester: Manchester University Press.

Sohn, L. B., \& Weiss, E. B. (1987). The Annual Meeting (American Society of Internationa 1 Law ) 81 . In Intergenerational Equity in International Law (p. 131).

Supreme Court of the Philippines. Minors Oposa v. The Honorable Fulgencio S. Factoran, Jr., 33 I.L.M. 173 (1994).

Tol, R. S. J. (1999). The Marginal Costs of Greenhouse Gas Emissions. The Energy Journal, 20(1), 7071.

Turner, R. K., Pearce, D., \& Bateman, I. (1993). Environmental Economics: An Elementary Introduction. Baltimore: Johns Hopkins University Press.

Weiss, E. B. (1996). Intergenerational Equity and Rights of Future Generation. In A. A. C. Trindade (Ed.), The Modern World of Human Rights: Essays in Honour of Thomas Buergenthal (pp. 608609). San José, Costa Rica: InterAmerican Institute of Human Rights. World Commission on Environment and Development. Report of the World Commission on Environment and Development: Our Common Future (1987). Retrieved from http://www.un-documents.net/wcedocf.htm 